\title{
ACCOUNTING OUTSOURCING: CURRENT STATE AND PROBLEMS OF PRACTICAL IMPLEMENTATION
}

\section{АУТСОРСИНГ БУХГАЛТЕРСЬКОГО ОБЛІКУ: СУЧАСНИЙ СТАН ТА ПРОБЛЕМИ ПРАКТИЧНОГО ВПРОВАДЖЕННЯ}

\section{Olena Koba ${ }^{1}$}

DOI: https://doi.org/10.30525/978-9934-26-077-3-32

Abstract. The purpose of the article is to determine the theoretical and organizational principles of application of accounting outsourcing by business entities. Methodology. Methods of analysis and synthesis were used to determine the characteristics and features of the organization of accounting outsourcing. The generalization of the existing experience of application of accounting outsourcing is carried out by a monographic method. On the basis of economic analysis and comparison, trends in the development of accounting outsourcing are identified. Methodology. The development of outsourcing is explained by its ability to increase the competitiveness of products, to promote the introduction of the latest advances in scientific and technological progress, to optimize costs. The application of knowledge and experience of specialists specializing in solving certain issues allows to focus the resources of companies on the development of strengths and promising areas and not to spend extra effort and money on the development of new non-core activities. The generalization of statistics on the current state of outsourcing in Ukraine shows that its effective application is hampered by the lack of free financial resources to invest in new management technologies, lack of awareness of business entities about the experience of outsourcing and the market of outsourcing services, lack of legal mechanisms. Generalization of functionally-oriented, cooperative, managerial, instrumental, integrated, situational, complex approaches gives grounds for outsourcing to understand the management tool, which allows to concentrate the resources of the business entity on the

\footnotetext{
${ }^{1}$ Candidate of Technical Sciences, Associate Professor, Associate Professor at the Department of Finance, Banking and Taxation, National University «Yuri Kondratyuk Poltava Polytechnic», Ukraine

(C) Olena Koba
} 
main activity, provides profit growth and increase competitiveness through contractual transfer, non-core functions of specialists or companies that specialize in their implementation and perform more efficiently than the entity. Among the advantages of outsourcing there are reducing the cost of accounting, improving service quality, accountability, confidentiality, tax optimization, reducing the likelihood of fraud by employees, ensuring impartiality and objectivity of accounting, access to additional resources in the field of finance, accounting and tax calculations. However, outsourcing has certain disadvantages, namely the risk of information leakage, possible lack of efficiency, formal performance of duties, liquidation of the outsourcing company, loss of control over own resources and part of the case may be lost, additional time to agree on the terms of the contract. Minimize the disadvantages of outsourcing allows careful and reasonable choice of outsourcing company, which should take into account: data privacy guarantee, staff qualifications, cost of services, reputation, popularity, experience of the outsourcer in the market, flexibility in organizing services, application of the latest technical solutions, outsourcing it has standards of interaction and internal procedures.

\section{1. Вступ}

Сучасні умови господарювання спонукають керівництво компаній 3 метою успішної підприємницької діяльності і підвищення рівня конкурентоспроможності шукати та застосовувати нові форми управління бізнесом, однією з яких є аутсорсинг.

Аутсорсинг - інструмент оптимізації витрат, що дозволяє компаніям зосередити увагу на основних бізнес-процесах і ефективно вирішувати стратегічні завдання.

Широке впровадження аутсорсингу бухгалтерського обліку в сучасних умовах обумовлює актуальність дослідження теоретичних і практичних засад механізму його застосування суб'єктами господарювання.

Метою дослідження $є$ визначення теоретичних і організаційних засад застосування аутсорсингу бухгалтерського обліку суб'єктами господарювання.

Досягнення зазначеної мети передбачає вирішення наступних завдань:

- узагальнення наукових підходів до трактування поняття «аутсорсинг» і виявлення характерних рис аутсорсингу бухгалтерського обліку; 
- визначення переваг та недоліків запровадження аусторсингу бухгалтерського обліку;

- оцінка сучасного стану та виявлення проблем впровадження аутсорсингу бухгалтерського обліку в Україні.

Предметом дослідження є теоретичні, методичні та організаційні засади застосування аутсорсингу бухгалтерського обліку суб'єктів господарювання.

У процесі дослідження удосконалено понятійно-термінологічний апарат теорії бухгалтерського обліку шляхом уточнення поняття «аутсорсинг бухгалтерського обліку»; визначено тенденції розвитку аутсорсингу бухгалтерського обліку в Україні; встановлено характерні ознаки, переваги та недоліки запровадження аусторсингу бухгалтерського обліку.

\section{2. Розвиток аутсорсингу бухгалтерського оокіу в Україні}

Запорукою ефективної діяльності підприємства $є$ надійна система бухгалтерського обліку. Тому питання організації обліку будь-якого суб'єкта господарювання є його першочерговим завданням.

Останнім часом зростає частка суб'єктів господарювання, в першу чергу, таких, що належать до малого та середнього бізнесу, які вважають неекономічним та нераціональним створювати власну бухгалтерську службу, оскільки обсяг облікової роботи на них, зазвичай, незначний. Такі суб'єкти господарювання залучають до ведення бухгалтерського обліку спеціалізовані аудиторські та аутсорсингові компанії.

Термін «аутсорсинг» («outsourcing») походить від англійських слів «outside resource using» і означає «використання зовнішніх ресурсів». У міжнародній практиці він означає послідовність організаційних рішень, сутність яких полягає у передачі певних, раніше самостійно реалізованих підприємством функцій або видів діяльності іншому підприємству.

Сьогодні, завдяки аутсорсингу, забезпечено високі темпи економічного розвитку в Японії, США, Німеччині, Франції та ін. За даними журналу Fortune мінімум 90\% сучасних підприємств хоча б для одного бізнес-процесу використовують аутсорсинг.

Опитування керівників 1700 американських компаній, проведене у 2018 році Bill.com та СРА.com свідчить: 
- 80 \% опитаних вважають, що аутсорсинг дозволяє зосередитись на основному бізнесі,

- 68 \% - що, завдяки аутсорсингу, бухгалтерський облік стає ефективнішим,

- 50 \% стверджують, що знижується вірогідність помилок у звітності,

- 28 \% засвідчили, що поради аутсорсингових компаній сприяли підвищенню прибутку,

- $31 \%$ опитаних аутсоринг допоміг прийняти важливі бізнес-рішення.

Україна за даними американської консалтингової компанії «А.Т. Kearney» у 2019 році за своїм аутсорсинговим потенціалом зайняла 20 місце в ТОП-25 глобального рейтингу «Global Services Location Index», піднявшись на чотири позиції порівняно з 2018 роком. Це було зумовлено збільшенням витрат на інфраструктуру та показників ділового середовища, що компенсувало нижчий за середній бал цифрового резонансу та четверте за величиною зниження рівня кваліфікації людей [1].

У рейтингу Best of The Global Outsourcing 100, який складає міжнародна асоціація IAOP, у 2018 році представлені 17 компаній з офісами в Україні [2].

При цьому за рівнем популярності в Україні аутсорсинг бухгалтерського обліку займає шосте місце після аутсорсингу IT-послуг $(40,5 \%)$, логістики $(35,1 \%)$, ресурсного забезпечення виробничих процесів (27 \%), маркетингових послуг (21,6 \%), рекрутменту $(18,9 \%)$ (рисунок 1) [3].

Найбільшими 3 аутсорсингових компаній в Україні є міжнародні компанії «Ernst\&Young», «Pricewaterhouse Coopers», «Deloitte», «KPMG», «McKinsey», які займають 75\% ринку. Серед решти компаній за даними редакції SBR, визначеними на підставі таких показників як кількість клієнтів, послуг, співробітників, співвідношення ціна-якість послуг, обіг, рівень обслуговування, до ТОП-5 входять «ЕВS», «Дмитрієва та Партнери», «Finance Solutions Group», «Nota Group», «BDO», наступні п’ять позицій займають компанії: «Дебет і кредит», «Elma Consulting», «Global Consulting», ГК «ОЛ. Консалтинг», ГК «Сова» [4].

Широке впровадження аутсорсингу в сучасний бізнес обумовлено наступними обставинами: 


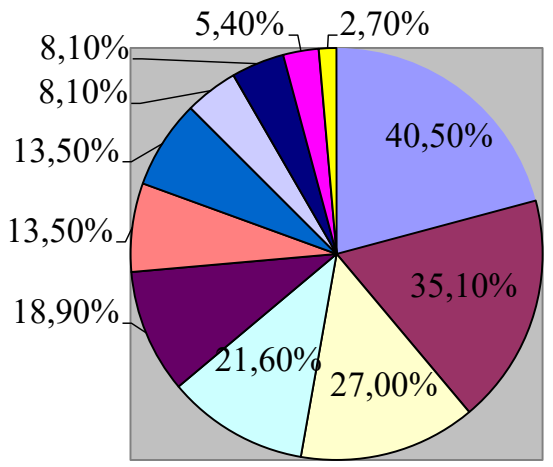

$\square$ IT-послуги

口логістика

$\square$ ресурсне забезпечення виробничих процесів

$\square$ маркетингові послуги

$\square$ рекрутмент

口бухгалтерські послуги

$\square$ розрахунок заробітної плати

$\square$ обробка і систематизація інформації

- аутсорсинг медичних представників

口облік кадрів і кадровий супровід

$\square$ адміністративні функції

\section{Рис. 1. Популярність видів аутсорсингу в Україні}

Джерело розроблено авторами за даними [3]

1. Більшість сучасних компаній розуміє важливість впливу на забезпечення конкурентоспроможності продукції впровадження новітніх досягнень науково-технічного прогресу і прагне їх застосувати у своїй діяльності.

2. Сучасні наука, техніка, технології $є$ настільки розгалуженими, що охопити їх в повному обсязі та мати досконалі знання і досвід в усіх потрібних сферах не під силу жодній компанії, якою б великою вона не була. Запорукою успіху у майбутньому має стати користування послугами фахівців, які надають необхідні послуги компаніям на умовах аутсорсингу. В такому разі компанія може зосередити власні ресурси на розвитку своїх сильних сторін і перспективних напрямів та не витрачати додаткові зусилля й кошти на освоєння нових неосновних видів діяльності.

3. Застосування аутсорсингу дозволяє оптимізувати витрати на виробництво продукції, сприяє зниженню іiі собівартості, i, в свою чергу, ціни на неї, а тому відповідає інтересам споживачів, які отримують продукт найкращої якості за доступною ціною.

Аналізуючи сучасний стан аутсорсингу в Україні варто відзначити, що він постійно розвивається та набирає обертів. Проте, забезпечення ефективного його застосування вимагає подальших досліджень умов функціонування, оптимальних моделей аутсорсингу, методів зниження рівня ризику аутсорсингових послуг тощо. 


\section{3. Сутність аутсорсингу бухгалтерського обліку}

Визначенню сутності поняття «аутсорсинг» присвячені праці Айвазяна 3.С., Бравара Ж., Бурденко І., Дідух О., Загороднього А., Зорій О., Каледжяна С., Коваленко Т., Ляхович Г., Матвія І., Мікало О., Моргана Р., Хейвуда Дж., Осадчого О., Партин Г., Поплюйка А., Семанюк В., Скакун Л., Фрідмана Т., Чмут А. та інших. Проведені дослідження дозволили науковцям запропонувати трактування поняття «аутсорсинг» (таблиця 1), які, на нашу думку, можна об'єднати у декілька підходів: функціонально-орієнтований, коопераційний, управлінський, інструментальний, інтегрований, ситуаційний, комплексний.

Таблиця 1

\section{Підходи до трактування поняття «аутсорсинг» в науковій літературі}

\begin{tabular}{|c|c|}
\hline $\begin{array}{c}\text { Прізвище, імя, } \\
\text { по-батькові } \\
\text { науковця }\end{array}$ & Авторське тлумачення поняття «аутсорсинг» \\
\hline 1 & 2 \\
\hline Айвазян 3.С. [5] & $\begin{array}{l}\text { Аутсорсинг - це передавання певних допоміжних функцій } \\
\text { третій особі, яка спеціалізується в певній галузі }\end{array}$ \\
\hline $\begin{array}{c}\text { Бравар Ж.-Л., } \\
\text { Морган Р. } \\
\text { [6] }\end{array}$ & $\begin{array}{l}\text { Аутсорсинг - це обумовлене договором використання матері- } \\
\text { альних засобів, майна та знань третьої особи з гарантованим } \\
\text { рівнем якості, гнучкості та цінності вартісних критеріїв і оцінок } \\
\text { для надання послуг, які раніше надавалися за рахунок внутріш- } \\
\text { них сил компанії, з можливим переходом наявного персоналу } \\
\text { до постачальника послуг та/або трансформацією/оновленням } \\
\text { процесів або технологій, що підтримують бізнес }\end{array}$ \\
\hline $\begin{array}{c}\text { Бурденко I.М., } \\
\text { Ярошина А.П. } \\
\text { [7] }\end{array}$ & $\begin{array}{l}\text { Аутсорсинг - це обумовлене договором використання матері- } \\
\text { альних засобів, майна та знань третьої особи з гарантованим } \\
\text { рівнем якості, гнучкості та цінності вартісних критеріїв і оцінок } \\
\text { для надання послуг, які раніше надавалися за рахунок внутріш- } \\
\text { ніх сил компанії, із можливим переходом наявного персоналу } \\
\text { до постачальника послуг та/або трансформацією/оновленням } \\
\text { процесів або технологій, що підтримують бізнес }\end{array}$ \\
\hline $\begin{array}{c}\text { Давидюк Т.В., } \\
\text { Легоцька Ю.І. } \\
\text { [8] }\end{array}$ & $\begin{array}{l}\text { Під аутсорсингом будемо розуміти передачу на договірних } \\
\text { умовах внутрішніх непрофільних функцій підприємства } \\
\text { (споживача аутсорсингових послуг), а в ряді випадків } \\
\text { також активів стороннім виконавцям (аутсорсерам), що } \\
\text { спеціалізуються в певній сфері та володіють значними } \\
\text { знаннями, досвідом, технічним оснащенням. }\end{array}$ \\
\hline
\end{tabular}


(Продовження таблиці 1)

\begin{tabular}{|c|c|}
\hline 1 & 2 \\
\hline Дідух О.В. [9] & $\begin{array}{l}\text { Аутсорсинг - інструмент управління підприємством, спрямова- } \\
\text { ний на підвищення ефективності та конкурентоспроможності } \\
\text { діяльності, який передбачає укладання контракту між замовни- } \\
\text { ком (підприємством) і постачальником (аутсорсером) з метою } \\
\text { виконання останнім як основних, так і допоміжних бізнес-функ- } \\
\text { цій і бізнес-процесів замовника за певну плату, що зумовлює } \\
\text { реорганізацію та оптимізацію підприємницької діяльності } \\
\text { замовника та тимчасове залучення відповідного персоналу. }\end{array}$ \\
\hline $\begin{array}{c}\text { Загородній А.Г., } \\
\text { Партин Г.О. } \\
{[10]}\end{array}$ & $\begin{array}{l}\text { Аутсорсинг - це передавання частини функцій з } \\
\text { обслуговування діяльності підприємства стороннім } \\
\text { підрядникам чи постачальникам за умови гарантування } \\
\text { ними відповідного рівня якості та ефективності їх виконання } \\
\text { на основі трансформації чи оновлення бізнес-процесів і } \\
\text { технологій та з можливістю переходу частини персоналу } \\
\text { підприємства до постачальника (аутсорсера) }\end{array}$ \\
\hline $\begin{array}{c}\text { Зорій О.М., } \\
\text { КоваленкоТ.В. } \\
\text { [11] }\end{array}$ & $\begin{array}{l}\text { Аутсорсинг - цілеспрямоване виокремлення певних } \\
\text { бізнес-процесів та їх реалізація іншими організаціями, які } \\
\text { мають відповідний досвід, знання, засоби та виконують } \\
\text { свої обов’язки в конкретній сфері краще, ніж організація- } \\
\text { замовник, і на договірній основі }\end{array}$ \\
\hline $\begin{array}{c}\text { Календжян С.О. } \\
{[12]}\end{array}$ & $\begin{array}{l}\text { Аутсорсинг - це відмова від власного бізнес-процесу } \\
\text { протягом обумовленого в договорі терміну та придбання } \\
\text { послуг із реалізації цього бізнес-процесу в іншої компанії }\end{array}$ \\
\hline $\begin{array}{c}\text { Матвій I.C. } \\
\text { [13] }\end{array}$ & $\begin{array}{l}\text { Аутсорсинг являє собою спосіб ефективного } \\
\text { функціонування підприємства за рахунок зосередження } \\
\text { діяльності на головному напрямі. }\end{array}$ \\
\hline $\begin{array}{c}\text { Микало О.І. } \\
{[14]}\end{array}$ & $\begin{array}{l}\text { Аутсорсинг - це інструмент посилення } \\
\text { конкурентоспроможності підприємства за рахунок } \\
\text { концентрації на ключових, виходячи з ринкових умов, для } \\
\text { підприємства функціях та/або бізнес-процесах }\end{array}$ \\
\hline $\begin{array}{c}\text { Перетятько А.Ю. } \\
{[15]}\end{array}$ & $\begin{array}{l}\text { Аутсорсинг - передача традиційно неключових функцій органі- } \\
\text { зації (таких, наприклад, як бухгалтерський облік або рекламна } \\
\text { діяльність) зовнішнім виконавцям - аутсорсерам, субпідрядни- } \\
\text { кам, висококваліфікованим спеціалістам сторонньої фірми. }\end{array}$ \\
\hline $\begin{array}{c}\text { Поливана Л.А. } \\
\text { [16] }\end{array}$ & $\begin{array}{l}\text { Аутсорсинг - напрям сучасного розвитку та управління } \\
\text { підприємства, який спрямований на підвищення } \\
\text { конкурентоспроможності діяльності, що передбачає укладання } \\
\text { контракту між замовником і постачальником із метою } \\
\text { виконання останнім як основних, так і другорядних бізнес- } \\
\text { функцій замовника за певну плату і зумовлений конкретними } \\
\text { ситуаціями управління в умовах невизначеності та ризику. }\end{array}$ \\
\hline
\end{tabular}


(Закінчення таблиці 1)

\begin{tabular}{|c|c|}
\hline 1 & 2 \\
\hline $\begin{array}{c}\text { Поплюйко А.M. } \\
{[17]}\end{array}$ & $\begin{array}{l}\text { Аутсорсинг - передача організацією на підставі договору } \\
\text { певних бізнес-процесів або виробничих функцій на } \\
\text { обслуговування іншій компанії, що спеціалізується у } \\
\text { цій галузі. Іншими словами, це спосіб ведення бізнесу, } \\
\text { при якому виконання робіт по деяким видам діяльності } \\
\text { передається стороннім компаніям. }\end{array}$ \\
\hline $\begin{array}{c}\text { Фрідман Т.Л. } \\
\text { [18] }\end{array}$ & $\begin{array}{l}\text { Аутсорсинг - це один із десяти найбільш вагомих факторів, } \\
\text { що визначають характер розвитку світової економіки на } \\
\text { сучасному етапі }\end{array}$ \\
\hline $\begin{array}{c}\text { Хейвуд Дж.Б. } \\
\text { [19] }\end{array}$ & $\begin{array}{l}\text { Аутсорсинг - це передавання внутрішнього підрозділу або } \\
\text { підрозділів підприємств і всіх пов'язаних із ним активів } \\
\text { в організацію постачальника послуг, що пропонує надати } \\
\text { певну послугу протягом певного часу за домовленою ціною }\end{array}$ \\
\hline $\begin{array}{l}\text { Чмут А.В., } \\
\text { Осадчий О.Д. } \\
{[20]}\end{array}$ & $\begin{array}{l}\text { Аутсорсинг - процес перенесення/передачі внутрішніх } \\
\text { функції або бізнес-процесів сторонньому виконавцеві, } \\
\text { або процес придбання ресурсів і послуг, які забезпечують } \\
\text { функціонування основної діяльності, у зовнішніх } \\
\text { контрагентів; або сучасна методологія/стратегія } \\
\text { організації бізнесу, в основу якої покладене рішення } \\
\text { щодо реструктуризації бізнес-моделі компанії з метою } \\
\text { забезпечення конкурентних переваг за рахунок підвищення } \\
\text { економічної ефективності діяльності, утримання ключових } \\
\text { компетенцій, перетворення бізнес-моделі, створення } \\
\text { стратегічних альянсів та бізнес-мереж }\end{array}$ \\
\hline
\end{tabular}

Джерело: узагальнено авторами за [5-20]

Прихильники функціонально-орієнтованого підходу (Айвазян 3., Хейвуд Дж., Календжян С., Перетятько А., Поплюйко О., Давидюк Т., Легоцька Ю., Загородній А.Г., Партин Г.) розглядають аутсорсинг як процес передачі виконання певних функцій компанії назовні з метою зменшення витрат.

Томас Фрідман - автор коопераційного підходу до трактування поняття аутсорсингу, вважає аутсорсинг одним 3 найбільш вагомих факторів, які визначають характер розвитку економіки світу на сучасному етапі.

Науковці, які підтримують управлінській підхід (Бравар Ж.-Л., Морган Р., Бурденко І.М., Ярошина А.П., Матвій І.С.), хоч і вважають аутсорсинг процесом передачі бізнес-процесів назовні, але наголошують на його ролі як моделі управління компанією. 
Інструментальний підхід (Микало О., Дідух О.) представляє аутсорсинг як інструмент досягнення конкурентних переваг, які пов'язані не лише зі зниженням собівартості продукції, а, насамперед, з необхідністю зосередити увагу на основній діяльності - ядрі бізнесу.

Чмут А.В., Осадчий О.Д. на підставі аналізу наведених наукових підходів пропонують інтегрований підхід щодо розуміння «аутсорсингу» як процесу «перенесення/передачі внутрішніх функції або бізнес-процесів сторонньому виконавцеві, або процесу придбання ресурсів і послуг, які забезпечують функціонування основної діяльності, у зовнішніх контрагентів; або сучасної методології/стратегії організації бізнесу, в основу якої покладене рішення щодо реструктуризації бізнес-моделі компанії з метою забезпечення конкурентних переваг за рахунок підвищення економічної ефективності діяльності, утримання ключових компетенцій, перетворення бізнес-моделі, створення стратегічних альянсів та бізнес-мереж».

Поливана Л.А., звертає увагу на те, що існує безліч факторів, як у самій організації, так і у зовнішньому середовищі, не існує єдиного «кращого» методу управління, щодо конкретної ситуації, найефективнішим є той, що найбільш повно відповідає іiі суті. Центральним моментом ситуаційного підходу, який вона пропонує застосовувати, $\epsilon$ ситуація - конкретний склад обставин, які значно впливають на підприємство в даний момент. Ситуаційний підхід намагається розв'язати конкретні прийоми та концепції з конкретними ситуаціями, щоб досягти цілей підприємства, а також ті, що, скоріше за все, можуть вплинути на іiі успіх. Ситуаційний підхід - це важливий крок до вдосконалення організації та управління в умовах невизначеності та ризику, він додає гнучкості та динамізму в управлінні підприємством, тим самим допомагаючи йому розвиватись.

Доречним є зауваження Зорій О, Коваленко Т., які стверджують, що наведені підходи не унеможливлюють, а вигідно доповнюють один одного. На їхню думку, «аутсорсинг становить цілеспрямоване виокремлення певних бізнес-процесів та їх реалізацію іншими організаціями, які мають відповідний досвід, знання, засоби та виконують свої обов'язки в конкретній сфері краще, ніж організація-замовник, і на договірній основі». Автори вважають, що використання аутсорсінгу зводиться до зосередження всіх ресурсів під- 
приємства на основному виді діяльності і передачі інших функцій надійному партнеру.

Враховуючи все вище сказане, пропонуємо власне тлумачення поняття аутсорсингу: аутсорсинг - інструмент управління, який дозволяє зосередити ресурси суб'єкта господарювання на основній діяльності, забезпечує зростання прибутку та підвищення конкурентоспроможності за рахунок передачі на договірній основі певних неосновних функції фахівцям або компаніям, що спеціалізуються на їх виконанні і здійснюють ефективніше, ніж даний суб'єкт господарювання.

Аналізуючи наведене визначення, можна виділити такі основні риси аутсорсингу (рисунок 2). Як свідчать дані рисунку 1, головною ознакою аутсорсингу є гарантії відповідальності та тривалого співробітництва з боку виконавця. Крім того, аутсорсинг підвищує конкурентоспроможність компаній, які його використовують, що, у свою чергу, дозволяє покращити якість обслуговування споживачів.

Аутсорсинг бухгалтерського обліку є окремим видом аутсорсингу бізнес-процесів, одним із способів облікового забезпечення діяльності

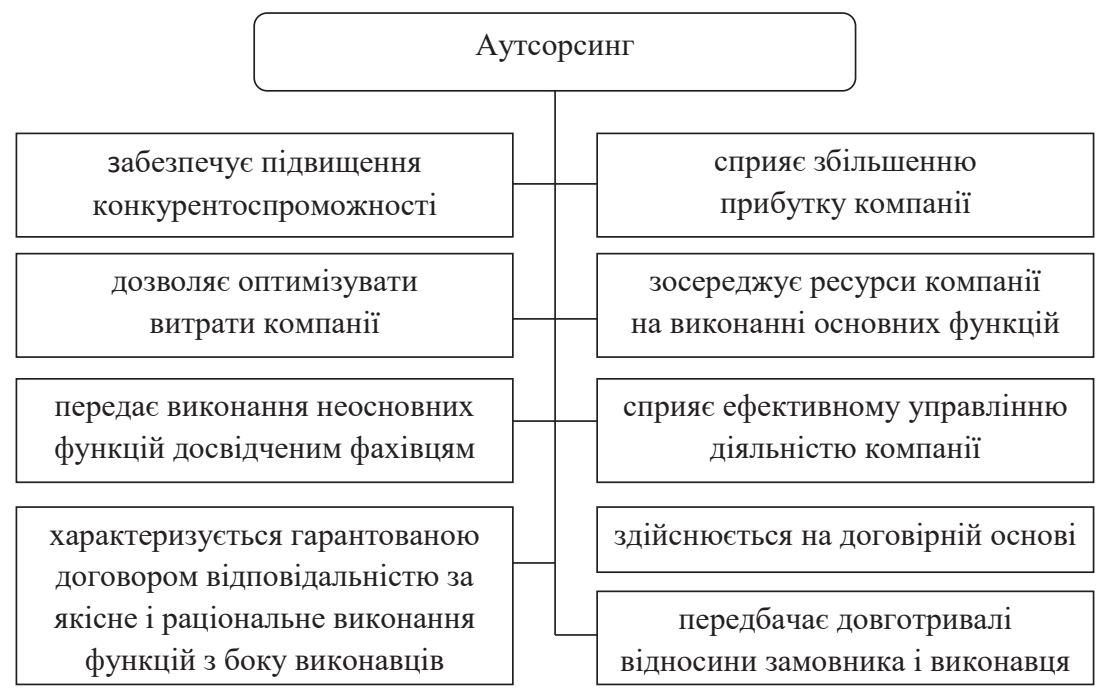

Рис. 2. Характерні риси аутсорсингу

Джерело: розроблено авторами 
підприємства. Він передбачає винесення функцій, пов'язаних з організацією, здійсненням бухгалтерського обліку і складанням фінансової, статистичної, податкової звітності за межі компанії, передачу їх для виконання аутсорсеру. На відміну від бухгалтерських послуг, що надаються внутрішніми виконавцями, аутсорсинг бухгалтерського обліку $є$ формою взаємодії, при якій зовнішня компанія включається в робочі бізнес-процеси компанії-замовника як цілісний функціональний підрозділ, залишаючись при цьому організаційно і юридично самостійним [4].

Аутсорсинг бухгалтерського обліку - це послуга, що дає можливість підприємствам доручити виконання складних завдань більш компетентним компаніям, здатним допомогти в питаннях ведення бухгалтерського та податкового обліку, оцінити можливості посилення конкурентоспроможності підприємства. Такі завдання якісно виконують консалтингові та аудиторські компанії, співробітники яких постійно підвищують кваліфікацію не лише у напрямку обліку, а й економічного аналізу та фінансового менеджменту. Це дозволяє фокусувати увагу не лише на достовірному відображенні фактів господарської діяльності, а й на пошуку резервів підвищення іiї ефективності.

\section{4. Переваги та недоліки аутсорсингу бухгалтерського обліку}

Для досягнення позитивних результатів та забезпечення максимальної ефективності аутсорсинг бухгалтерського обліку повинен базуватися за наступних принципах:

1. Взаємовигідність сторін співпраці.

2. Прозорість.

3. Збереження та захист комерційної таємниці.

4. Гнучкість надання послуг.

5. Ефективність та результативність.

6. Системність.

Тільки їх дотримання дозволяє замовнику в повному обсязі отримати переваги від застосування аутсорсингу, серед яких слід виділити [21; 22]:

- зменшення витрат на утримання бухгалтерської служби. Для обладнання навіть одного робочого місця бухгалтера потрібні меблі, оргтехніка, програмне забезпечення і канцелярське приладдя;

- підвищення якості послуг. В компаніях, які спеціалізуються на наданні послуг з бухгалтерського обліку, всі бізнес-процеси відпра- 
цьовані, що дозволяє набагато швидше вирішувати як складні, так і рутинні питання. При цьому аутсорсером пропонується одночасна робота декількох фахівців, які є його штатними працівниками: юристів, фахівців з оподаткування, трудового законодавства. За роботою спеціаліста, що забезпечує облік діяльності компанії-клієнта, здійснюється контроль, iї перевіряє начальник відділу бухгалтерського обліку та внутрішній аудитор. Аутсорсер володіє пакетами сучасних юридичних і облікових програм, що дозволяє йому оперативно реагувати на зміну законодавства, це також покращує якість наданих ним послуг, гарантує правильне та своєчасне складання звітності;

- відповідальність. При передачі ведення бухгалтерського обліку замовник захищений положеннями договору, згідно з яким саме аутсорсер відповідає за наслідки при наданні послуг з бухгалтерського обліку у разі виникнення помилок, прорахунків, втрат і псування документації, ненавмисного порушення законодавства;

- конфіденційність. Аутсорсер та його клієнт є бізнес-партнерами, ïх інтереси збігаються, тому вони укладають угоду про збереження в таємниці інформації, отриманої при виконанні договору для уникнення втрат і попередження нанесення шкоди інтересам клієнта;

- оптимізація податків. Спеціалізована бухгалтерська компанія узагальнює досвід сотень своїх кліснтів з найрізноманітніших сфер бізнесу. Отримані від аутсорсера послуги з обліку замовник може включити до складу витрат i, відповідно, до податкового кредиту з ПДВ;

- зниження ймовірності махінацій з боку найманого персоналу підприємства, адже аутсорсер не має реального доступу до грошей, чи інших матеріальних активів, а також здатний оцінити ефективність їх витрат порівняно з усередненими показниками на ринку;

- забезпечення неупередженості та об'єктивності обліку. В аутсорсингових компаніях працюють лише високо кваліфіковані спеціалісти, які постійно складають атестації на знання бухгалтерських програм, змін у законодавстві, навичок роботи з комп'ютером та програмним забезпеченням та інші. Навчання, підготовка кадрів та подальше атестування проводиться за рахунок аутсорсинової фірми, а не клієнта;

- доступ до додаткових ресурсів у сфері фінансів, бухгалтерського обліку та податкових розрахунків; 
- зосередження уваги на основному виді діяльності, інвестиційний капітал можна перерозподілити у стратегічно більш важливу для підприємства діяльність.

Оцінюючи переваги аутсорсингу бухгалтерського обліку, варто враховувати, що він має і певні недоліки, серед яких можна виділити:

- можлива відсутність оперативності. При передачі сторонній організації всього циклу бухгалтерського документообігу існує ризик втрати оперативності даних;

- ризик витоку інформації;

- формальне виконання обов'язків. Звіти, які складає аутсорсер, є формальним виконанням зобов'язань перед відповідними органами;

- ліквідація фірми-аутсорсера. В разі припинення роботи фірмою необхідно протягом невеликого проміжку часу знайти нового постачальника аутсорсингових послуг, та як можна скоріше налагодити 3 ним процес співпраці чи почати вести облік самостійно;

- контроль над власними ресурсами та частиною справ може бути втрачено;

- додаткові витрати часу на узгодження умов договору [21; 22].

Для мінімізації наведених недоліків необхідно дуже виважено підходити до організації переходу на аутсорсинг.

\section{5. Висновки}

Аналіз становлення та розвитку аутсорсинг бухгалтерського обліку в Україні і світі свідчить, що він постійно розвивається та набирає обертів. Однак використанню аутсорсингу в Україні перешкоджає: відсутність вільних фінансових ресурсів для інвестування, недостатня поінформованість суб'єктів господарювання про досвід впровадження аутсорсингу; відсутність законодавчих механізмів регулювання партнерських взаємовідносин при аутсорсингу.

Узагальнення існуючих наукових підходів до визначення поняття «аутсорсинг», дозволяе стверджувати, що під аутсорсингом слід розуміти інструмент управління, який дозволяє зосередити ресурси суб'єкта господарювання на основній діяльності, забезпечує зростання прибутку та підвищення конкурентоспроможності за рахунок передачі на договірній основі певних неосновних функції фахівцям або компа- 
ніям, що спеціалізуються на їх виконанні і здійснюють ефективніше, ніж даний суб'єкт господарювання.

Аутсорсинг характеризується тим, що забезпечує підвищення конкурентоспроможності, дозволяє оптимізувати витрати компанії, сприяє збільшенню прибутку і ефективному управлінню діяльністю компанії, зосереджує іiї ресурси на виконанні основних функцій. Серед переваг аутсорсинг варто виділити: зниження витрат на утримання бухгалтерії, підвищення якості послуг, відповідальність за результат, конфіденційність, оптимізацію податків, зниження ймовірності махінацій з боку найманого персоналу підприємства, забезпечення неупередженості та об'єктивності обліку, доступ до додаткових ресурсів у сфері фінансів, бухгалтерського обліку та податкових розрахунків. При цьому аутсорсинг має недоліки, серед яких: ризик витоку інформації, можлива відсутність оперативності, формальне виконання обов'язків, ліквідація фірми-аутсорсера, втрата контролю над власними ресурсами та частиною справ може бути втрачено, додаткові витрати часу на узгодження умов договору.

На вибір аутсорсера підприємством впливають наступні фактори: гарантія збереження конфіденційності даних, кваліфікація персоналу та вартість послуг аутсорсера, стаж роботи аутсорсера на ринку, гнучкість при організації надання послуг, застосування новітніх технічних рішень аутсорсером, його популярність, перелік послуг, що пропонується аутсорсером, наявність у нього стандартів взаємодії та внутрішніх процедур, репутація аутсорсера.

\section{Список літератури:}

1. URL: https://www.kearney.com/digital-transformation/gsli/2019-full-report (дата звернення: 15.12.2020).

2. URL: https://dou.ua/lenta/news/outsourcing-top-100-2019/ (дата звернення: 15.12.2020).

3. Красношапка В.В., Трохимець I.I. Аутсорсинг та його застосування на підприємствах України. Ефективна економіка. 2015. № 5. URL: http://www.economy.nayka.com.ua/?op=1\&z=4097 (дата звернення: 15.12.2020).

4. URL: http://www.sbr.in.ua/?p=2589 (дата звернення: 15.12.2020).

5. Айвазян 3.С. Бизнес на «пустом месте». Финансист. 2002. № 4. С. 25.

6. Бравар Ж.-Л., Морган Р. Ефективний аутсорсинг: розуміння, планування та використання успішних аутсорсингових відносин. Дніпропетровськ : Баланс Бізнес Букс, 2007. 288 с. 
7. Бурденко I.М., Ярошина А.П. Аутсорсинг: поняття, види та сучасний стан розвитку. Приазовський економічний вісник. 2018. Випуск 6(11). C. 513-518.

8. Давидюк Т.В., Легоцька Ю.І. Бухгалтерський аутсорсинг як інноваційний інструмент досягнення економічних переваг. Економічний журнал Одеського політехнічного університету. 2018. № 1. С. 11-18.

9. Дідух О.В. Основні види аутсорсингу в господарській діяльності підприємств. Вісник Хмельницького національного університету. 2012. № 2. C. $29-33$.

10. Загородній А.Г., Партин Г.О. Аутсорсинг та його вплив на витрати підприємства. Фінанси України. 2009. № 9(166). С. 87-97.

11. Зорій О.М., Коваленко Т.М. Особливості застосування аутсорсингу. Економічний аналіз: збірник наукових пращь Тернопільського національного економічного університету. 2013. Т. 14. № 3. С. 18-28.

12. Каледжян С.О. Аутсорсинг сегодня - это фордовский конвейер 100 лет назад: второе дыхание бизнеса? Управление персоналом. 2010. № 3. C. $15-22$.

13. Матвій I.Є. Особливості розвитку IT-аутсорсингу в Україні. Вісник Наиіонального університету «Львівська політехніка». Проблеми економіки та управління. 2013. № 754. C. 185-190. URL: http://nbuv.gov.ua/UJRN/ VNULPP $2013 \quad 754 \quad 28$

14. Микало О.І. Аналіз та класифікація форм аутсорсингу. Економічний nростір. 2010. № 37. C. 216-222.

15. Перетятько А.Ю. Забезпечення конкурентних переваг підприємства на основі аутсорсингу бізнес-процесів. Комунальне господарство міст. Науковотехнічний збірник. 2014. № 113. С. 209-213.

16. Поливана Л.А. Ситуаційний підхід до визначення терміну «аутсорсинг». Науковий вісник Полтавського університету економіки $і$ торгівлі. 2014. № 2(64). C. 139-145.

17. Поплюйко А.М. Бухгалтерський аутсорсинг: сучасний стан та перспективи розвитку в Україні. Фінанси, облік і аудит. 2011. № 18. С. 335-340.

18. Фридман, Т. Плоский мир: Краткая история XXI века. Москва : АСТ: ACT, 2006. $601 \mathrm{c}$.

19. Heywood J. Brian. The Outsourcing Dilemma: The Search for Competitiveness. Financial Times. Prentice Hall. 2001. 240 p.

20. Чмут А.В., Осадчий О.Д. Сутність аутсорсингу та тенденцій його розвитку на міжнародних ринках. Глобальні та національні проблеми економіки. 2017. Випуск 17. С. 116-119.

21. Кесарчук Г.С. Бухгалтерський аутсорсинг: поняття, види, переваги та недоліки. Науковий вісник Ужгородського університету. Серія Економіка. 2014. Випуск 1(42). С. 201-204.

22. Sneidere R., Bumane I., Lascenko J. Accounting outsourcing services in Latvia problems and possible solutions. Accounting, Auditing, Taxation and Governance. 2013. Vol. 18(1). Pp. 26-38. 


\section{Olena Koba}

\section{References:}

1. URL: https://www.kearney.com/digital-transformation/gsli/2019-full-report (accessed 15 April 2021)

2. URL: https://dou.ua/lenta/news/outsourcing-top-100-2019/ (accessed 15 April 2021).

3. Krasnoshapka V.V., Trokhymecj I.I. (2015). Autsorsyngh ta jogho zastosuvannja na pidpryjemstvakh Ukrajiny [Outsourcing and its application at Ukrainian enterprises]. Efficient economy, vol. 5. Retrieved from: http://www.economy.nayka.com.ua/ ?op $=1 \& z=4097$ (accessed 15 April 2021).

4. URL: http://www.sbr.in.ua/?p=2589 (accessed 15 April 2021).

5. Ajvazjan Z.S. (2002). Byznes na «pustom meste» [Business in an «empty place»]. Financier, no. 4, p. 25.

6. Bravar Zh.-L., Morghan R. (2007). Efektyvnyj autsorsyngh: rozuminnja, planuvannja ta vykorystannja uspishnykh autsorsynghovykh vidnosyn [Effective Outsourcing: Understanding, Planning, and Using Successful Outsourcing Relationships]. Dnepropetrovsk: Balance Business Books, 208 p. (in Ukrainian)

7. Burdenko I.M., Jaroshyna A.P. (2018). Autsorsyngh: ponjattja, vydy ta suchasnyj stan rozvytku [Outsourcing: concepts, types and current state of development]. Priazovsky Economic Bulletin, vol. 6(11), pp. 513-518.

8. Davydjuk T.V., Leghocjka Ju.I. (2018). Accounting outsourcing as an innovative tool to achieve economic benefits [Bukhghaltersjkyj autsorsyngh jak innovacijnyj instrument dosjaghnennja ekonomichnykh perevagh]. Economic Journal of Odessa Polytechnic University, no. 1, pp. 11-18.

9. Didukh O.V. (2012). Osnovni vydy autsorsynghu v ghospodarsjkij dijaljnosti pidpryjemstv [The main types of outsourcing in the economic activity of enterprises]. Bulletin of Khmelnytsky National University, vol. 2, pp. 29-33.

10. Zaghorodnij A.Gh., Partyn Gh.O. (2009). Autsorsyngh ta jogho vplyv na vytraty pidpryjemstva. [Outsourcing and its impact on enterprise costs]. Finance of Ukraine, no. 9(166), pp. 87-97.

11. Zorij O.M., Kovalenko T.M. (2013). Osoblyvosti zastosuvannja autsorsynghu. Ekonomichnyj analiz: zbirnyk naukovykh pracj [Features of outsourcing]. Economic analysis: a collection of scientific works of Ternopil National Economic University, vol. 14, no. 3, pp. 18-28.

12. Kaledzhjan S.O. (2010). Autsorsyngh seghodnja - эto fordovskyj konvej'er 100 let nazad: vtoroe dykhanye byznesa? [Kaledjian SO Outsourcing today is a Ford pipeline 100 years ago: the second breath of business?]. Personnel management, no. 3, pp. 15-22.

13. Matvij I.Je. (2013). Osoblyvosti rozvytku IT-autsorsynghu v Ukrajini [Features of the development of IT outsourcing in Ukraine]. Bulletin of the National University «Lviv Polytechnic». Problems of economics and management, no. 754, pp. 185-190. Retrieved from: http://nbuv.gov.ua/UJRN/VNULPP_2013_754_28 (accessed 15 April 2021).

14. Mykalo O.I. (2010). Analiz ta klasyfikacija form autsorsynghu [Analysis and classification of forms of outsourcing]. Economic space, no. 37, pp. 216-222. 
15. Peretjatjko A.Ju. (2014). Zabezpechennja konkurentnykh perevagh pidpryjemstva na osnovi autsorsynghu biznes-procesiv [Providing competitive advantages of the enterprise on the basis of outsourcing of business processes]. Municipal utilities. Scientific and technical collection, no. 113, pp. 209-213.

16. Polyvana L.A. (2014). Sytuacijnyj pidkhid do vyznachennja terminu «autsorsyngh» [Situational approach to the definition of the term «outsourcing»]. Scientific Bulletin of Poltava University of Economics and Trade, no. 2(64), pp. 139-145.

17. Popljujko A.M. (2011). Bukhghaltersjkyj autsorsyngh: suchasnyj stan ta perspektyvy rozvytku v Ukrajini [Accounting outsourcing: current state and prospects of development in Ukraine]. Finance, accounting and auditing, no. 18, pp. 335-340.

18. Frydman, T. (2006). Ploskyj myr: Kratkaja ystoryja XXI veka [The flat world: A brief history of the XXI century]. Moscow: AST: AST MOSCOW: Keeper, 601 p. (in Russian)

19. Heywood J. Brian. (2011). The Outsourcing Dilemma: The Search for Competitiveness. Financial Times. Prentice Hall, 240 p.

20. Chmut A.V., Osadchyj O.D. (2017). Sutnistj autsorsynghu ta tendencij jogho rozvytku na mizhnarodnykh rynkakh [The essence of outsourcing and trends in its development in international markets]. Global and national economic problems, vol. 17, pp. 116-119.

21. Kesarchuk Gh.S. (2014). Bukhghaltersjkyj autsorsyngh: ponjattja, vydy, perevaghy ta nedoliky [Accounting outsourcing: concepts, types, advantages and disadvantages]. Scientific Bulletin of Uzhgorod University. Economics series, vol. 1(42), pp. 201-204.

22. Sneidere R., Bumane I., Lascenko J. (2013). Accounting outsourcing services in Latvia problems and possible solutions. Accounting, Auditing, Taxation and Governance, vol. 18(1), pp. 26-38. 